\title{
Acetogenins of Annona muricata leaves: Characterization and potential anticancer study
}

\author{
Nik Nurul Najihah Nik Mat Daud ${ }^{1}$, Harisun Ya'akob ${ }^{1,2 *}$ and Mohamad Norisham Mohamad Rosdi ${ }^{1}$ \\ ${ }^{1}$ Department of Bioprocess Engineering, Faculty of Chemical and Energy Engineering, Universiti Teknologi Malaysia, Malaysia \\ ${ }^{2}$ Institute of Bioproduct Development, Department of Bioprocess Engineering, Faculty of Chemical and Energy Engineering, Universiti Teknologi Malaysia, \\ Malaysia
}

\begin{abstract}
Annona muricata L. is belongs to the family Annonacea, which has been used in many traditional medicinal systems. It has many medicinal values such as to cure fever, headaches, cough, asthma and hypertension. Such bioactive chemical compounds identified through characterization compounds analysis. The analysis of bioactive and acetogenins compounds in the crude plant extracts involving the applications of common identification and characterization technique involving nonchromatographic techniques such as phytochemical screening and metabolites quantification, Nuclear Magnetic Resonance (NMR) and Fourier-Transform Infrared (FT-IR) along with chromatographic technique such as High Performance Liquid Chromatography (HPLC) are discussed. The evaluation of cytotoxicity study on normal and cancer cell lines was accessed with no alteration occurred in the normal Periodontal Ligament (PDL) cell line and showed some inhibition in colon cancer (HT-29) cell line. The presence of bioactive compound is confirmed as the valuable medicinal compound likely to cure vast array of disease.
\end{abstract}

\section{Introduction}

Plants are the better source of pharmacologically active compounds, and have provided humankind with many medically usually compounds for centuries. Medicinal plants are containing substances which are responsible for healing properties not exactly known until 19th century [1]. Medicinal plants have many phytochemical which are naturally occurring in the leaves, vegetables and roots that have defence mechanism and protect properties [2]. The phytochemicals were non-nutritive plant chemicals that have protective or disease preventive properties. They were non-essential nutrients, meaning that they were not required by the human body for sustaining life. However, it was well-known that plant produced these chemicals to protect themselves and recent research demonstrated that they can also protect humans against diseases. There were more than thousand known phytochemicals and each worked differently. Some of the well-known phytochemicals were alkaloids, terpenoids (stimulation of enzymes), phenolic and flavonoids (antioxidants), phlobatanins, tannins, fatty acids, leucoanthocyanins, coumarins, saponin (interference with DNA replication), and steroids The modern pharmaceutical researches have been intensively tried to found out the active principles in the plants. The active principles differ from plant to plant, even differ in the different organ of the same plant, there are mainly due to their diversity of bioactive compounds in the plant. Since the isolation and separation of compound is very difficult and time consuming, it becomes harder to identify and validated the active compounds in crude extract. To identify and authenticate the compounds in the crude plant extract, some of non-chromatographic and chromatographic techniques can be done. Identification of active principles or known as biologically active maker compound requires their standardization using appropriate chemical procedures such as chromatographic and spectral studies [3]. One of the important herbal plant Annona muricata L. or known as soursop attracts greater attention because it's high medicinal value both in herbal folklore practices and also the lack of adequate information on the nature of bioactive principle and its therapeutic action. In ancient time, it had been used as herbal remedies in treating diabetes, hypertension, fever, vomiting and against worm [4]. Other than that, it also has been used in treating headaches, cough, asthma and as a sedative [5-7]. The soursop as commonly known, is a mediumsized tree. Prior to its high antioxidant and anticancer compounds, the leaves composition of this plant include polysaccharide, protein, glycosaponin, phenolic, and flavonoid showed medicinal properties as antioxidant agent. The leaves are rich in annonaceous acetogenin, the most potent anticancer compounds. The annonaceous acetogenins compounds are composed of a series of polyketide-derived fatty acid with tetrahydrofuran rings and methylated gamma-lactone bonded together. Present investigation focus on the identification of bioactive compound present in that valuable medicinal plant by HPLC, NMR and FT-IR spectral investigation and the aim of the cytotoxicity study was done to determine the effects induced by the sample on normal and cancer cell line.

\section{Materials and methods}

\section{Extract}

The Annona muricata leaves extract was obtained from the optimization process using soxhlet extractor continuous from previous study [8]. The dried leaves were extracted in a soxhlet by using different ratio of solvent to raw material ratio in the range of 1:1 to 1:6 with different ethanol concentration $0-10 \%$ and extraction time 1 to 8

Correspondence to: Harisun Yảakob, Department of Bioprocess Engineering, Faculty of Chemical and Energy Engineering, Universiti Teknologi Malaysia, Skudai, Johor 81310, Malaysia, E-mail: harisun@ibd.utm.my

Key words: annonacea, acetogenins, chromatographic, non-chromatographic

Received: July 17, 2016; Accepted: Augest 11, 2016; Published: Augest 14, 2016 
hr. The extracts were filtered using Whatman No. 1 filter paper. The filtrate was then evaporated to dryness using rotary evaporator (Buchi Evaporator, Heidolph, Germany) at $50^{\circ} \mathrm{C}$. The dried crude extract was obtained from oven drying method at $40^{\circ} \mathrm{C}$ (Mermet) and the samples were stored in a freezer of $(-20)^{\circ} \mathrm{C}$ for further analysis. The marker compound from the optimum extract was validated through characterization and identification process.

\section{Identification and characterization}

Phytochemical Screening: Phytochemical screening tests were carried out in the extracts using standard procedure to identify the constituents as described by Trease and Evans [9]. The screening involved detection of alkaloids, terpenoids, flavonoids, coumarins, steroids, fatty acids, phlobatanins, phenolics, tannins, and saponin. The method used in this study were shown in Table 1.

Primary and Secondary Metabolites Quantification: Primary and secondary metabolites quantification included several antioxidant tests such as total polysaccharide measurement [10], total protein measurement [11-12], total glycosaponins measurement [10] and [13] total phenolic [14] and total flavonoid content [15]. The antioxidant activity also was studied using DPPH Radical Scavenging Activity Assay. All sample were measured by Shimadzu UVmini-1240 of UV-Vis spectrophotometer (Shimadzu Corporation, Kyoto, Japan). The radical scavenging activity of samples was investigated using 2,2, diphenylpicryl-Hydrazyl (DPPH) method as described by Norshazila [16] with slight modification. Each sample was prepared in a twofold series of dilution and was mixed with the DPPH reagent. After 30 minutes of incubation at room temperature in the dark, the absorbance was taken against blank at $517 \mathrm{~nm}$ using UV-VIS spectrophotometer. The two commercial antioxidants used as positive control were ascorbic acid (vitamin C) and butylated hydroxyanisole (BHA). At the same time, the negative control was also prepared using solvent extractor mixed with DPPH reagent. At the end of experiment, the result was expressed in mean average and the free radical scavenging activity was calculated according to the following equation below:

$$
\text { \%inhibition }=\left[\frac{A_{0}-A_{e}}{A_{0}}\right] \times 100 \%
$$

where,

$\mathrm{A}_{0}=$ Absorbance reading of the negative control

\section{$\mathrm{A}_{\mathrm{e}}=$ Absorbance reading in the presence of sample}

High performance liquid chromatography: Acetogenins qualitative screening analysis was carried out using HPLC with operating conditions that matched those reported by Yang [17] with slightly modification. A water HPLC system (Milford, MA, USA) that consisted of double pump and system controller (Model 2695), an auto-sampler and photo-diode array detector (Model 966) was used. The column configuration consisted of a reversed phase column $(4.6 \times 150 \mathrm{~mm}, 4 \mu \mathrm{m}$; Phenomemex, Torrance, CA, USA). Detection wavelength was set at $220 \mathrm{~nm}$. The mobile phase consisted of A (acetonitirile) and B (deionized water), using a linear gradient: 0-40 $\min (85 \%)$, and $40-60 \mathrm{~min}(85-95 \% \mathrm{~A})$. The flow rate was $1.0 \mathrm{ml} / \mathrm{min}$. The column temperature was maintained at $30^{\circ} \mathrm{C}$. High Performance of Liquid Chromatography (HPLC) was used for the screening of the acetogenins compounds present in the plant extracts, and also for the assessment of the pharmaceutical properties of the capsules.

Nuclear magnetic resonances (NMR): Nuclear Magnetic Resonance Spectroscopy was an operation technique used for liquid NMR experiment using a Bruker Avance NMR $400 \mathrm{MHz}$ model. NMR was the final technique for molecular characterization or more specifically molecular determination. The $1 \mathrm{H} \mathrm{NMR}(400 \mathrm{MHz})$ and 13C NMR (100 MHz) spectra were recorded on Bruker Avance 400 spectrometer. The chemical shifts were reported in $\mathrm{ppm}$ relative to tetramethylsilane (TMS) in deuterium oxide $(2 \mathrm{H} 2 \mathrm{O})$ as solvents. The infrared spectra were measured using Perkin-Elmer series 1600 spectrophotometer as thin film $(\mathrm{NaCl})$ window for liquid samples or $\mathrm{KBr}$ pellet for solid samples. The melting points were measured on a Leica Gallen III Kofter micro melting point apparatus. The optical rotations were measured in $\mathrm{CHCl} 3$ with Perkin Elmer 241 polarimeter. The ultraviolet (UV) spectra were recorded on Shimadzu UV 1601PC spectrophotometer. NMR is a powerful tool in identification of molecular structure of the compounds in plant extract.

Fourier-transform infrared (FT-IR): FT-IR was used to identify the functional group of the active components based on the peak value in the region of infrared radiation. All spectra were obtained with the aid of an OMNI-sampler attenuated total reflectance (ATR) accessory on a FTIR spectrophotometer. A small amount of powdered leaves was placed directly on the germanium piece of the infrared spectrometer with constant pressure applied and data of infrared absorbance, collected over the wave number ranged from $4000 \mathrm{~cm}^{-1}$ to $675 \mathrm{~cm}^{-1}$

Table 1. Phytochemical screening.

\begin{tabular}{|c|c|c|}
\hline Test & Method & Indicator \\
\hline Alkaloids & $1 \mathrm{~mL}$ of extract was added with 2-3 drops of Mayer's reagent & $\begin{array}{l}\text { The appearance of cream colour precipitate or pale yellow colour precipitate } \\
\text { indicated the presence of alkaloids }\end{array}$ \\
\hline Terpenoids & $\begin{array}{l}1 \mathrm{~mL} \text { of the extract was mixed with } 2 \mathrm{~mL} \text { of chloroform and concentrated } \\
\mathrm{H}_{2} \mathrm{SO}_{4}(3 \mathrm{~mL}) \text { was carefully added to form a layer }\end{array}$ & $\begin{array}{l}\text { A reddish brown colouration of the interface was formed to indicate positive } \\
\text { results for the presence of terpenoids }\end{array}$ \\
\hline Flavonoids & $1 \mathrm{~mL}$ of extract was dissolved in diluted $\mathrm{NaOH}$ and $\mathrm{HCl}$ was added & A yellow solution that turns colourless indicated the presence of flavonoids \\
\hline Coumarins & $3 \mathrm{~mL}$ of $10 \% \mathrm{NaOH}$ was added to $2 \mathrm{~mL}$ of aqueous extract & Formation of yellow colour indicated the presence of coumarins. \\
\hline Steroids & $\begin{array}{l}1 \mathrm{~mL} \text { of the extract was dissolved in } 10 \mathrm{~mL} \text { of chloroform and equal volume } \\
\text { of concentrated sulphuric acid was added by sides of the test tube }\end{array}$ & $\begin{array}{l}\text { The upper layer turns red and sulphuric acid layer showed yellow with green } \\
\text { fluorescence. This indicated the presence of steroids. }\end{array}$ \\
\hline Fatty acids & $\begin{array}{l}1 \mathrm{~mL} \text { of extract was mixed with } 10 \mathrm{~mL} \text { of ether. These extract was allow it for } \\
\text { evaporation on filter paper and dried the filter paper }\end{array}$ & $\begin{array}{l}\text { The appearance of transparency on filter paper indicated the presence of fatty } \\
\text { acids. }\end{array}$ \\
\hline Phlobatanins & $\begin{array}{l}1 \mathrm{~mL} \text { of extract was dissolved in distilled water and filtered. The filtrate was } \\
\text { boiled with } 2 \% \mathrm{HCl} \text { solution }\end{array}$ & Red precipitate indicated the presence of phlobatanins \\
\hline Phenolics and Tannins & $\begin{array}{l}1 \mathrm{~mL} \text { of extract was dissolved in } 2 \mathrm{~mL} \text { of distilled water. Into this solution, a } \\
\text { few drops of } 5 \% \text { ferric chloride solution were added }\end{array}$ & $\begin{array}{l}\text { The formation of dark green colour indicated the presence of phenolic } \\
\text { compounds. }\end{array}$ \\
\hline Saponin & $\begin{array}{l}1 \mathrm{~mL} \text { of extract was diluted with distilled water up to } 3 \mathrm{~mL} \text {. The suspension } \\
\text { was then shaken in a test tube for } 15 \mathrm{~min}\end{array}$ & Formation of a two layer of foam indicated the presence of saponin. \\
\hline
\end{tabular}


and computerized for analyses). The melting points were measured on a Leica Gallen III Kofter micro melting point apparatus. The optical rotations were measured in $\mathrm{CHCl} 3$ with Perkin Elmer 241 polarimeter. The ultraviolet (UV) spectra were recorded on Shimadzu UV 1601PC spectrophotometer.

\section{Cell lines and culture}

HT-29 cells, colorectal cancer cells were obtained from Kuliyyah of Allied Health Science and preodontal ligament, PDL normal cells from Integrated Centre for Research Animal, Care \& Use, IIUM Kuantan. Cells were grown in Dulbecco's modified eagle medium (DMEM) with $10 \%(\mathrm{v} / \mathrm{v})$ fetal bovine serum \& $1 \%(\mathrm{v} / \mathrm{v})$ of penicillin streptomycin. Cells were cultured at $37^{\circ} \mathrm{C}$ in $5 \% \mathrm{CO}_{2}$ humidified atmosphere. Cells were sub cultured when it reached $>80 \%$ confluency.

\section{Cytotoxicity}

Trypan Blue exclusion method was a cell-based assay used in this study to detect the mechanism of toxicity in cells. Trypan Blue assay was widely used in cytotoxicity test and the cost was inexpensive. It assessed cell metabolic activity and was developed as a non-radioactive alternative for measuring cell proliferation. In Trypan Blue exclusion method, cell viability was determined by counting the unstained cells with a microscope. A cell suspension mixture that contained $50 \mu \mathrm{L}$ of cell suspension and $50 \mu \mathrm{L}$ of trypan blue was transfer carefully to the edge of coverslip that was placed on the haemocytometer. Viable cell concentration and viable cell percentage were calculated using following equations:

Percentage of viability $=\frac{\text { Number of unstained cells }}{\text { Total number of stained and unstained }} \times 100$ where,

Cell $/ \mathrm{mL}=$ the average count per square $\times$ dilution factor $\times 104$

Total cell $/ \mathrm{mL}=$ cell $/ \mathrm{mL} \times$ original volume from which sample is removed

After cell viability was determined, the cells were diluted with the required culture medium to prepare the seeding density of cell. Then, the diluted cells were seeded and incubated at $37^{\circ} \mathrm{C}$ in $5 \% \mathrm{CO}_{2}$ incubator. In this study, an experiment was carried out to evaluate and compare the toxicity induced by optimum soursop leaves extract and spray dried formulation in the same experimental set-up. Tryphan Blue Dye Exclusion method was used to determine cell viability by study the toxicity of both samples against PDL and HT-29 cell lines at different concentrations. This was very important because PDL and HT-29 reacted differently depending on samples concentration. Cells seeded at density of $4 \times 10^{4}$ cells $/ \mathrm{mL}$ in 6 well plates. After 24 hours of incubation, cells were washed and extract at IC50 was added for treated cells. For untreated cells, they were grown in complete growth media only. Cells were incubated in $5 \% \mathrm{CO}_{2} 95 \% \mathrm{O}_{2}$ at $37^{\circ} \mathrm{C}$ for 24 , 48 and 72 hours. Cells were counted at 24,48 and 72 hours to observe growth pattern of treated and untreated cells. Results were plotted by percentage in graph. Morphological of treated and untreated cells were analysed at same time with cell proliferation assay. Cells were examined for morphological changes at 24, 48 and 72 hours before the cells trypsinised for cell count using inverted phases contrast microscope.

\section{Results and discussion}

\section{Phytochemicals screening analysis}

The extract with optimum condition obtained was further screened
Table 2. Phytochemical Screening of the various extracts of the plant leaves.

\begin{tabular}{|l|c|}
\hline Name of Compound & Primary and Secondary Metabolites \\
\hline Polysaccharide & $21.85 \pm 0.001$ \\
\hline Protein & $19.59 \pm 0.000$ \\
\hline Glycosaponin & $18.87 \pm 0.001$ \\
\hline Phenolic & $24.39 \pm 0.001$ \\
\hline Flavonoid & $21.49 \pm 0.001$ \\
\hline
\end{tabular}

Key: $+=$ Presence of Secondary Metabolite, Content: $(+)=$ Little $(++)=$ Medium

Table 3. Percentage total contents of primary and secondary metabolites in soursop leaf.

\begin{tabular}{|l|c|}
\hline Name of Compound & Primary and Secondary Metabolites \\
\hline Polysaccharide (\%) & $21.85 \pm 0.001$ \\
\hline Protein (\%) & $19.59 \pm 0.000$ \\
\hline Glycosaponin (\%) & $18.87 \pm 0.001$ \\
\hline Phenolic (\%) & $24.39 \pm 0.001$ \\
\hline Flavonoid (\%) & $21.49 \pm 0.001$ \\
\hline
\end{tabular}

with phytochemical analysis test shown in table 2 .

In this qualitative analysis of phytochemical screening, the extract exhibited positive results for nine phytochemical tests included alkaloids, terpenoids, flavonoids, coumarins, steroids, fatty acids, phlobatanins, phenolics, tannins, and saponins were seen to be present in this extract. This finding was in the agreement with other previous studies which have been done on ethanolic and aqueous extract on soursop leaf for antibacterial effect. Based on the results obtained, soursop leaves exhibited positive results for alkaloids, saponins, terpenoids, flavonoids, coumarins and lactones, anthraquinones, tannins, cardiac glycosides, phenols and phytosterols [18-20]. In the study done by Usunomena [21], the soursop leaf contained flavonoids, alkaloids, cardiac glycoside, tannins, triterpenoid, saponin and reducing sugar. In this phytochemical studies, the characterization of bio-active compounds or different chemical groups with reference to the technical was described in the previous journal $[9,22,23]$. The findings indicated that soursop leaf was a potential source of highly nutritious ingredients and phytomedicine.

\section{Primary and secondary metabolites quantification}

The quantification of primary and secondary metabolites was analyzed by spectroscopic method. The primary metabolites test include polysaccharide, protein, and glycosaponin were performed on the extract obtained from the optimum condition to check the quantity of primary metabolites present in it. Prior to this objective, secondary metabolites tests for compounds such as phenolic and flavonoid were also tested on the extract to check the content of antioxidant compounds present in it. The quantitative analysis of primary and secondary metabolites test were reported as shown in Table 3.

Figure 1 showed the comparison of radical scavenging activity between the positive controls; ascorbic acid (Vit. C), butylated hydroxyanisole (BHA) and sample using 2, 2, diphenylpicryl-Hydrazyl (DPPH) assay method. In this DPPH reaction mixture, ascorbic acid was used as positive control gave the fastest color change from purple to yellow. As for the samples, high concentration of an optimum sample showed bleaching of purple color during eye observation. However, low concentration of soursop leaves extract showed no obvious purple bleaching effect, even though there were decreases in the absorbance readings. Likewise, Figure 1 shows that for positive control, butylated hydroxyanisole (BHA) contained higher radical scavenging activity compared to ascorbic acid (Vitamin C). Meanwhile extract sample also showed the highest percentage of scavenging activity with the $\mathrm{IC}_{50}$ value 


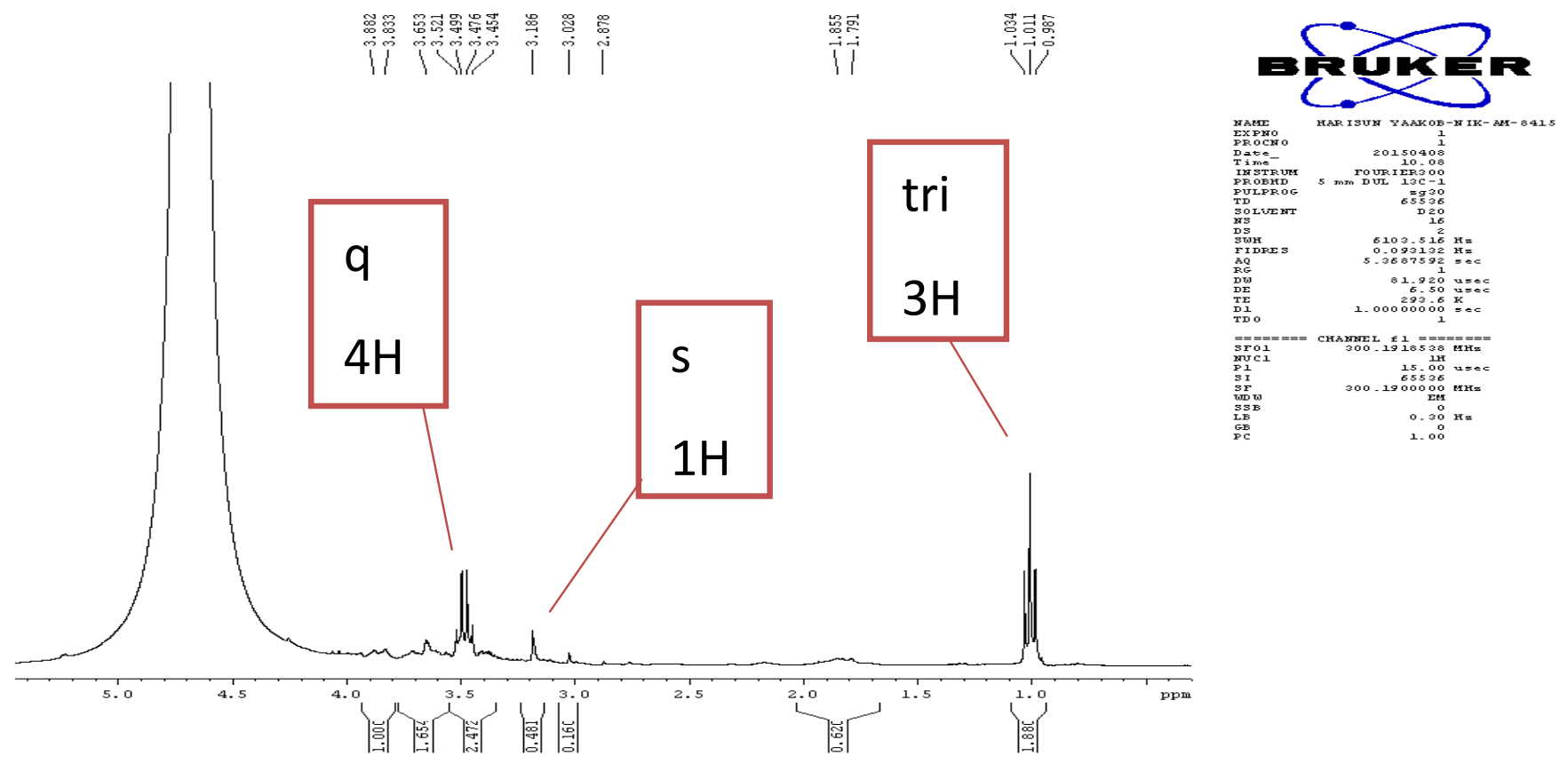

Figure 1. The presence of methyl, methylene, and methine group in H-1 NMR spectrum.

$(0.243 \pm 0.001 \mathrm{mg} / \mathrm{mL})$. However, the $\mathrm{IC}_{50}$ value for samples was still nearly the range of both positive controls, where $\mathrm{IC}_{50}$ value for $\mathrm{BHA}$ and Vit. $\mathrm{C}$ were $(0.155 \pm 0.001$ and $0.232 \pm 0.001 \mathrm{mg} / \mathrm{ml})$ respectively (Figures 2 and 3 ).

\section{High performance liquid chromatography analysis}

The optimum extract sample was screened through High Performance Liquid Chromatography (HPLC) according to Yang [24] with slightly modification. Representative chromatograms of the acetogenins analytes for the sample with optimum condition was illustrated in figure 3. The figure displayed that the six acetogenins compound analytes were well separated and detected in HPLC screening process. The resolution between any two compounds in the sample was greater than 1.5. Other compounds in the sample did not interfere with analysis of the six acetogenins compounds analytes.

The chromatographic peaks were identified by comparing their retention time with that of each reference compounds reported from the previous journal [13]. The retention times of the compound in the extract remained the same and the coefficient of variation for retention time was less than $1 \%$ which made a confirmation of the presence of acetogenins in the extract.

\section{Nuclear magnetic resonances analysis}

The presence of acetogenin compounds was detected by comparing the chromatographic profile of the extract with previous reported studies. The screening was focused on the first 60 minutes of chromatographic running where the desired compound was eluted.
In the meantime, to confirm the presence of acetogenin compounds in this extract, other chromatographic techniques were used in the screening process such as Nuclear Magnetic Resonance (NMR) and Fourier Transform Infrared (FTIR). In this study, ${ }^{1} \mathrm{H},{ }^{13} \mathrm{C}$ and DEPT experiments were obtained from NMR analysis prior to the HPLC screening to confirm the presence of acetogenins compound in the extract. Proton Nuclear Magnetic Resonance ( $\left.{ }^{1} \mathrm{H}-\mathrm{NMR}\right)$ spectrum was recorded to determine the number of protons in the molecule particularly in searching of hydroxyl functional group $(\mathrm{OH})$ for this study. All protons in the compound could be accounted from the integration of ${ }^{1} \mathrm{H}-\mathrm{NMR}$ spectrum and based on the results obtained in this analysis, there was no hydroxyl peak was found in this extract. The ${ }^{1} \mathrm{H}-\mathrm{NMR}$ (Figure 1) resonances revealed the existence of three proton triplet at $\delta 0.9$. The group was slightly deshielded, showing that it resided near a group, like $\mathrm{C}=\mathrm{C}$ or $\mathrm{C}=\mathrm{O}$. One proton singlet was also observed at $\delta 3.3$ followed by four proton quartets at $\delta 3.4$. It was because this signal was a singlet $(n+1=1 ; n=0)$, there cannot be any ${ }^{1} \mathrm{H}$ nuclei on the adjacent carbon. Turning to the low field side of the spectrum, there was a quartet $(4 \mathrm{H})$ at $3.4 \mathrm{ppm}$. Any quartet signal (n $+1=4)$ indicated that the methylene proton $(\mathrm{CH} 2)$ must have $(\mathrm{n}=3)$ neighbouring protons that can only be the $\mathrm{CH}_{3}$ group or $\mathrm{CH}_{2}$ and $\mathrm{CH}$ groups.

In order to know how the two groups were connected, the NMR spectroscopy must be incorporated with ${ }^{13} \mathrm{C}$ spectrum (Figure 4). The ${ }^{13} \mathrm{C}$ spectrum provided information of total number of carbon atoms in a compound where the number of peaks from the spectrum representing number of carbons. It had few signals and the most 


\section{Percentage of Radical Scavenging Activity}

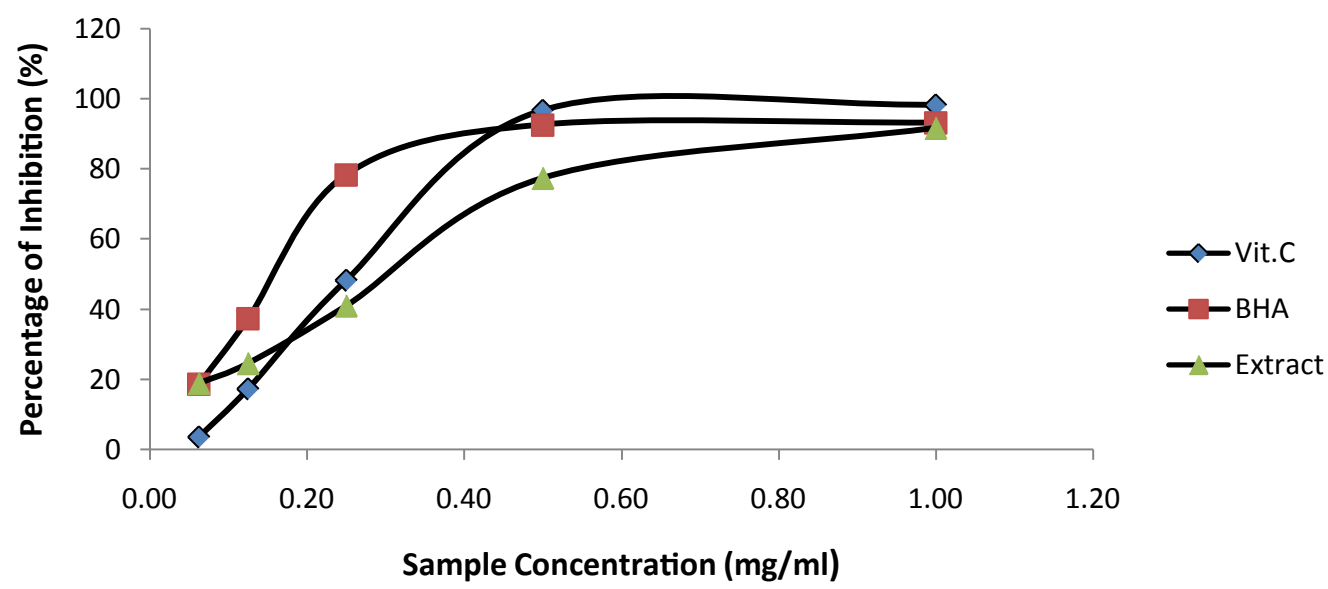

Figure 2. Comparison of radical scavenging activity between the positive controls; ascorbic acid (Vit. C), butylatedhydroxyanisole (BHA) and sample. $\mathrm{IC}_{50}$ value (in mg/mL) for each sample was derived from the graph at $50 \%$ radical scavenging activity.

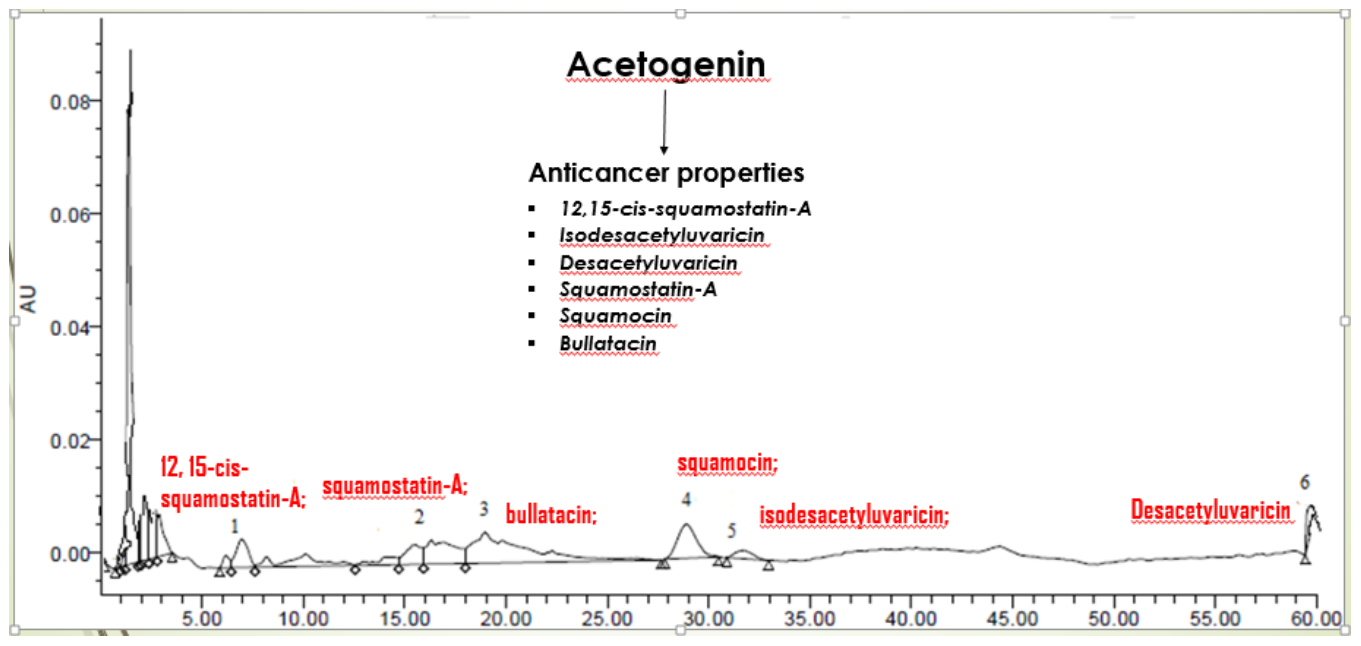

Figure 3. HPLC chromatograms of acetogenins compound was detected insoursop leaf. Peak identification: (1) 12, 15-cis-squamostatin-A; (2) squamostatin-A; (3) bullatacin; (4) Squamocin; (5) Isodesacetyluvaricin; (6) Desacetyluvaricin.

${ }^{13} \mathrm{C}$
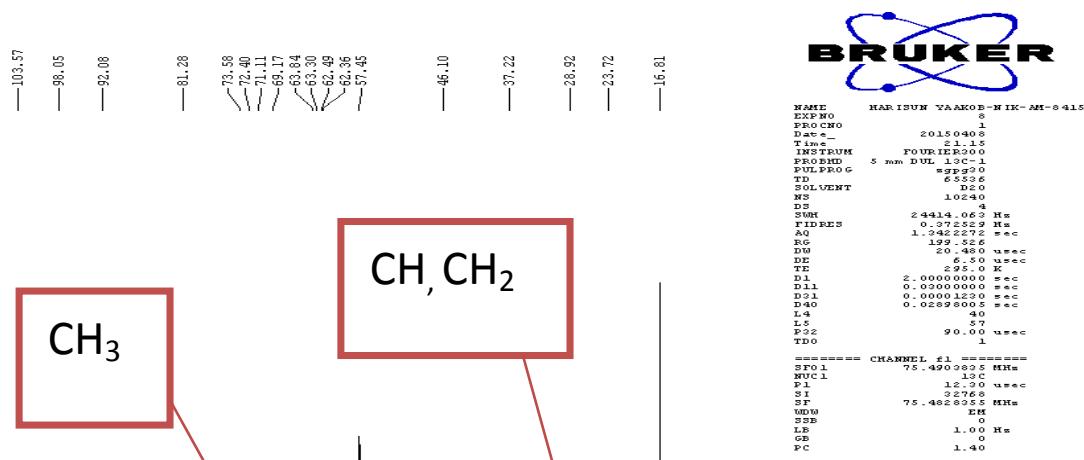
obvious signals were shift from 20 to $30 \mathrm{ppm}$ and 25 to $35 \mathrm{ppm}$ which indicated $\mathrm{CH}_{3} \mathrm{CO}-$ and $\mathrm{R}_{3} \mathrm{CH}$ group respectively. Meanwhile, the shift from 60 to $65 \mathrm{ppm}$ indicated $\mathrm{RCH}_{2} \mathrm{OH}$ group and 67 to $82 \mathrm{ppm}$ indicated alkynes group. The shift from $92 \mathrm{ppm}$ indicated the alkynes and $\mathrm{RC}=\mathrm{CH}$ group and $104 \mathrm{ppm}$ indicated alkene and aromatic group. Here, the combination or relation between $\mathrm{CH}, \mathrm{CH}_{2}$, and $\mathrm{CH}_{3}$ from the previous ${ }^{1} \mathrm{H}$ spectrum showed the confirmation of the analysis. This ${ }^{13} \mathrm{C}$ spectrum fully supports the structure derived. The peaks from this ${ }^{13} \mathrm{C}$ spectrum analysis were relatively shorter due to the lower concentration sample preparation but the confirmation of acetogenin compounds can be further confirmed and identified through FT-IR analysis.
DEPT stands for Distortionless Enhancement by Polarization Transfer which was a polarization transfer technique for the observation of nuclei with a small gyromagnetic ratio which were J-coupled to ${ }^{1} \mathrm{H}$ (most commonly ${ }^{13} \mathrm{C}$ ). In other word, DEPT was a spectral editing sequence that was used to generate separate ${ }^{13} \mathrm{C}$ subspectra for methyl $\left(\mathrm{CH}_{3}\right)$, methylene $\left(\mathrm{CH}_{2}\right)$, and methine $(\mathrm{CH})$ signals. In figure 5, there were three angles spectrum involved including DEPT $45^{\circ}$ sequence which yields spectra with positive $\mathrm{CH}, \mathrm{CH}_{2}$, and $\mathrm{CH}_{3}$ signals. DEPT $90^{\circ}$ sequence yields spectra with positive $\mathrm{CH}$ signals and DEPT $135^{\circ}$ yields spectra with positive $\mathrm{H}$ and $\mathrm{CH}_{3}$ signals and negative $\mathrm{CH}_{2}$ signals. Based on DEPT spectra, there were few number of peaks absent in DEPT $45^{\circ}$ spectrum when compared to ${ }^{13} \mathrm{C}$ spectrum. These peaks represented

\section{DEPT}

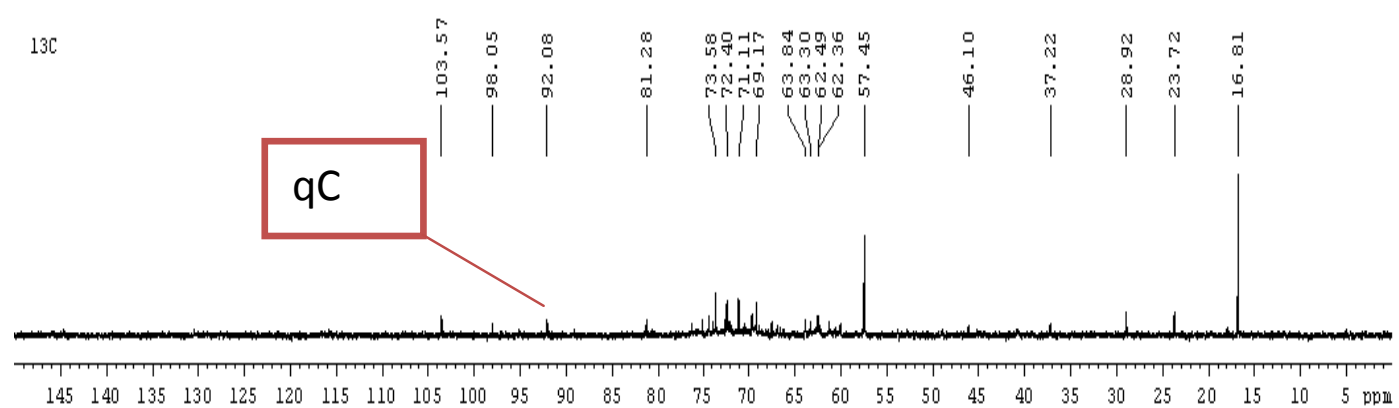

DEPT 45

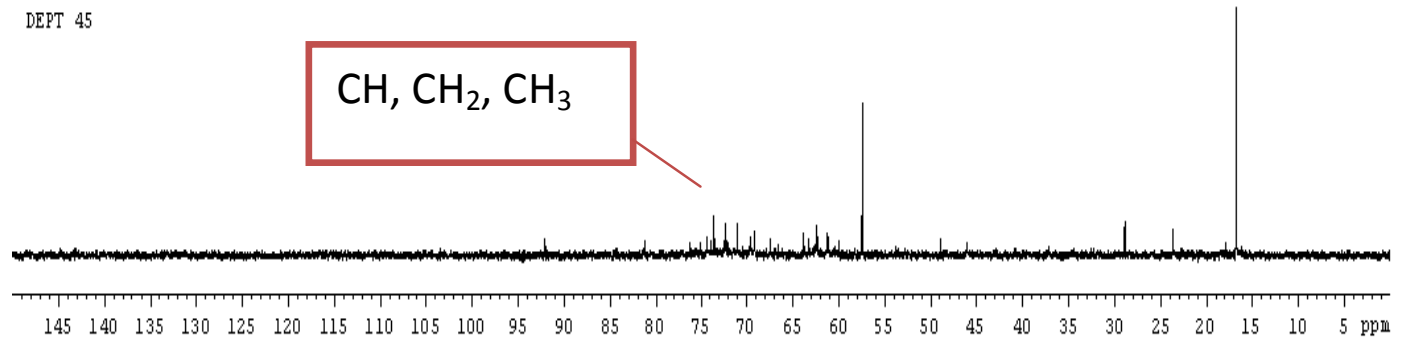

DEPT 90
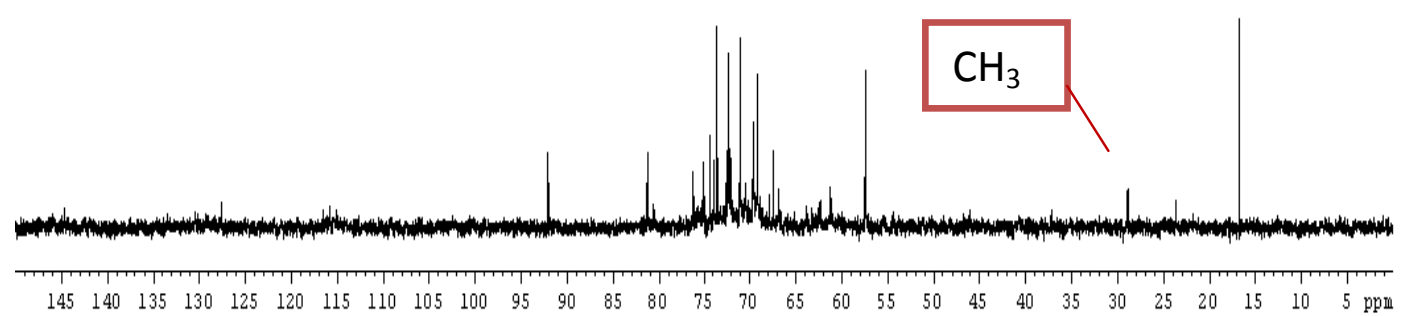

DEPT 135

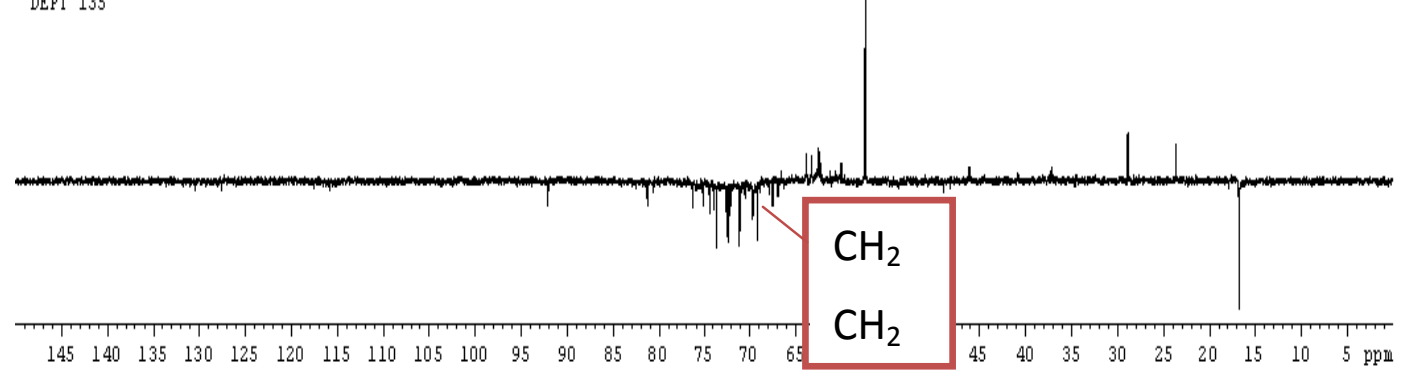

Figure 5. The DEPT analysis shows the existence of methyl, methylene, and methine group in H-1 NMR and in C-13 NMR spectrum. 
the quaternary carbons because it did not bound to any protons. The $45^{\circ}$ spectrum also showed the existence of $\mathrm{CH}, \mathrm{CH}_{2}$, and $\mathrm{CH}_{3}$ peaks. In $90^{\circ} \mathrm{DEPT}, \mathrm{CH}$ signal peaks were appeared on the upper spectrum similar like in $135^{\circ} \mathrm{DEPT}$. The existence of $\mathrm{CH}$ peak on the upper spectrum accompanied by $\mathrm{CH}_{3}$ peaks can be observed. The spectrum also revealed the existence of $\mathrm{CH}_{2}$ peaks in the down spectrum, a signal negative of the spectrum indicated the uniform result of ${ }^{1} \mathrm{H}$ and ${ }^{13} \mathrm{C}$ spectrum analysis which tallied to each other.

According to Chen [18], NMR spectroscopy can be carried out on crude plant extract without complex isolation and purification. The main problem is that the NMR spectrum provides low sensitivity, and it may be difficult to identify trace substances from the plants.
However, with the analysis obtained from FT-IR, the identification of compounds or molecules would be much easier since the functional group present in the extract could be identified wisely.

\section{Fourier-transform infrared spectroscopy analysis}

Fourier transform infrared spectrometry is a physico-chemical analytical technique that does not resolve the concentrations of individual metabolites but provides a snapshot of the metabolic composition of a tissue at a given time [19]. In this study, the soursop leaves extract was prepared into liquid and solid form for the test. Both were passed into the FTIR and the functional groups of the components were separated based on its peak ratio. The soursop leaves extract was rich with phytochemical contents as shown in previously test. In this

a)

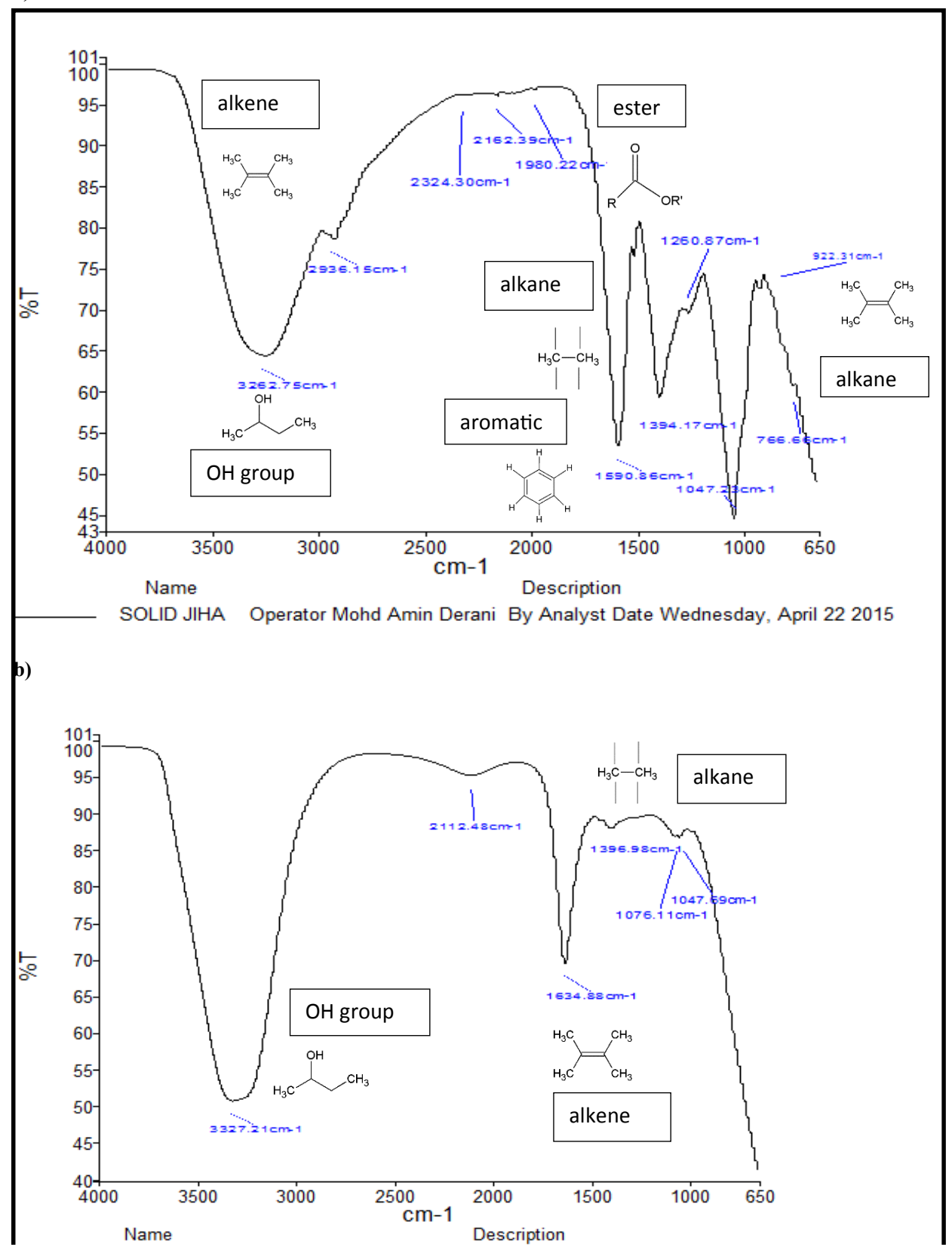

Figure 6. Fourier transform infrared (FTIR) spectra through Attenuated Total Reflectance Infrared (ATR-IR) from KBr analysis of annonaceousacetogenin from Annonamuricata leaves for solid (a) and liquid (b) form of the optimized crude extract. 
test, the results from the solid soursop leaves extract were compared to the liquid soursop leaves extract to check the confirmation of the functional group present in soursop leaves extract. Broad peak at $3262.75 \mathrm{~cm}^{-1}=\mathrm{OH}$ groups (Figure $6 \mathrm{a}$ ) compared to spectra of liquid form of sample $3327.21 \mathrm{~cm}-1=\mathrm{OH}$ groups (Figure 6b), $2936.15 \mathrm{~cm}-1$ $=\mathrm{CH}_{2}$ and $\mathrm{CH}$ alkenes groups (Figure 6a), bend peak at $1394.17 \mathrm{~cm}-1$ $=\mathrm{CH}_{3}$ alkane groups (Figure 6a), $1261 \mathrm{~cm}-1=\mathrm{COC}$ ester group (6a). As expected, in Figure (6a) the peak for $\mathrm{OH}$ groups remaining existed without the presence of solvent (deuterium oxide also known as water) confirming the peaks were from the sample. The IR spectrum revealed the presence of broad and strong adsorption of hydroxyl functional groups at $3262.75 \mathrm{~cm}^{-1}$.

Based on the structure of annonaceous acetogenins from soursop, the presence of alkanes, alkenes, ester, aromatic ring and hydroxyl groups in the extract can be detected through FT-IR analysis. Hence, a potentially broad number of molecular fragments of acetogenins compound can be considered to be functional groups attached to an organic structure or backbone from this soursop leaves extract. However, most of compounds considered to be positive present in this extract including 12, 15-cis-squamostatin-A, squamostatin-A, bullatacin, squamocin, isodesacetyluvaricin, and desacetyluvaricin confirmed the analysis results from HPLC screening.

\section{Tryphan blue dye exclusion viability cell count}

Figure 7 shown the viability of cell of optimum spray dried formulation on HT-29 colorectal cancer cell. It was observed that the percentage of cell inhibition increases with the increase of samples's concentration. At lower concentration, optimum spray dried anticancer formulation stimulate the growth cell. At concentration from $25 \mu \mathrm{g} / \mathrm{ml}$, the HT-29 cells started to suppressed significantly with $\mathrm{p}$-value is less than 0.05 . Using the trypan blue exclusion method, cells were harvested and viable cells counted using a haemocytometer at days indicated. The cells density of treated cells reduced significantly compared to untreated cells. This showed that both extracts did cause a suppression in proliferation on HT-29 cancer cell lines. The $\mathrm{IC}_{50}$ values for the optimized extract was $0.956 \mu \mathrm{g} / \mathrm{ml}$ showed that the optimized crude extract possess a higher IC $_{50}$ values. The morphological cells was observed under the microscope before the initial seeding and continued to observe after given the treatment. Based on the Figure 8, there is no alteration or proliferation occurred even at the highest concentration of samples. In figure 8 , both samples causes no toxicity or harm on normal PDL cell lines.

\section{Conclusion}

Since bioactive compounds occurring in plant material consist of

\section{HT-29 Proliferation}

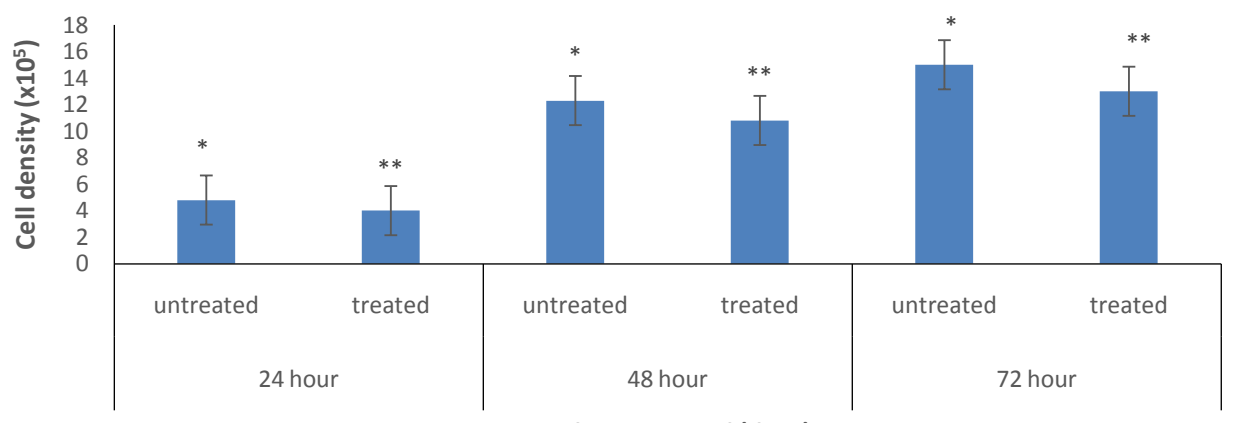

Incubation period (days)

- Optimized extract

Figure 7. Cytotoxic study of optimum crude extract on colon cancer cell, HT-29 cell lines. Results were expressed as mean for triplicate wells \pm SE $(* \mathrm{p}<0.05 ; * * \mathrm{p}<0.01)$

PDL

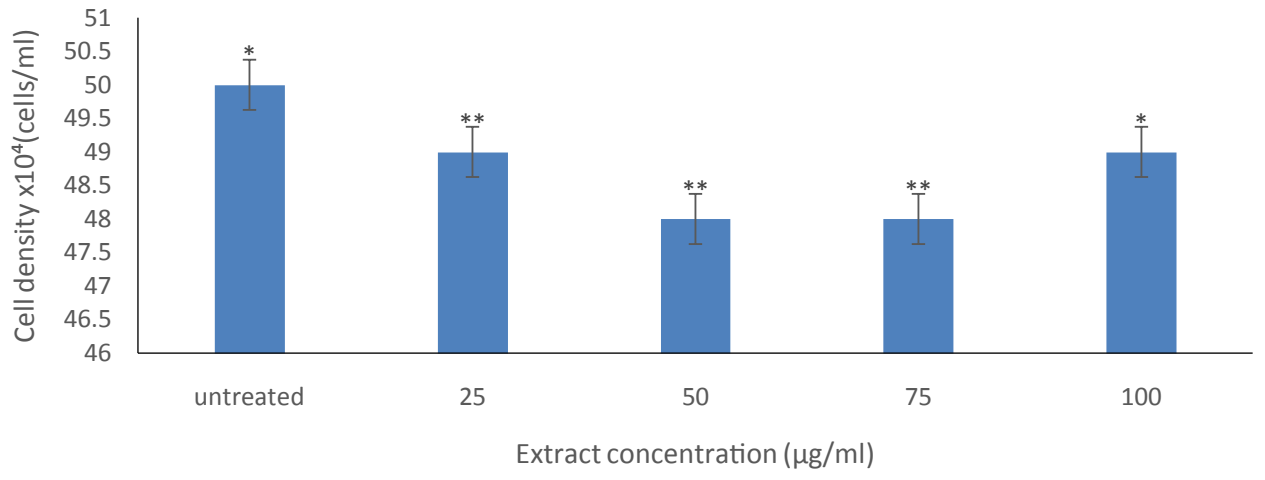

optimized extract

Figure 8. Cytotoxic study of optimum crude extract on normal PDL cell lines. Results were expressed as mean for triplicate wells \pm SE $\left({ }^{*} p<0.05 ; * * p<0.01\right)$. 
multi-component mixtures, their separation and determination still creates problems. Practically most of them have to be purified by the combination of several chromatographic techniques and various other purification methods to isolate bioactive compounds. However, the identification of the most potent anticancer compound (acetogenins) in A.muricata leaves has successfully determined through HPLC, NMR, and FT-IR techniques. Meanwhile, the cytotoxicity study showed that there is no apparent effect of the extract on normal PDL cell lines since the graph trending was similar among the samples with the untreated cells. Meanwhile in treating the cancer cells, HT29 (colon cancer) cell lines has been used and it was observed that the percentage of cell inhibition increases with the increase of samples' concentration.

\section{References}

1. Veeresham C (2012) Natural products derived from plants as a source of drugs. $J A d v$ Pharm Technol Res 3: 200-201. [Crossref]

2. Wadood A, Ghufran M, Jamal SB, Naeem M, Khan A, et al. (2013). Phytochemical analysis of medicinal plants occurring in local area of Mardan. Biochem Anal Biochem 2: $1-4$.

3. Paiva SR, Kaplan DE, Gottlieb OR (1995) An Acad Bras Cienc 67: 461-466.

4. Adjanohoun JE, Aboubakar N, Dramane K, Ebot ME, Ekpere JA, et al. (1996) Traditional medicine and pharmacopoeia: Contribution to ethnobotanical and floristic studies in Cameroon. OAU/STRC. 641.

5. Taylor L (2002) Graviola. Technical data report for Graviola, Annona Muricata. Sage Press, Austin. 1-18.

6. Lans CA (2006) Ethnomedicines used in Trinidad and Tobago for urinary problems and diabetes mellitus. J Ethnobiol Ethnomed 2: 45. [Crossref]

7. Berlowski A, Zawada K, Wawer I, Paradowska K (2013) Antioxidant properties of medicinal plants from Peru. Food and Nutrition Sciences 4: 71-77.

8. Nik Mat Daud NN, Mohamad Rosdi MN, Ya'akob H, Musa NF (2015) Optimization of soxhlet extraction parameter of Annona muricata leaves using Box-Behnken Design (BBD) expert and antioxidant analysis. Jurnal Teknologi 77: 27-37.

9. Trease GE, Evans WC (1987) Pharmacognsy (13 ${ }^{\text {th }}$ edn). Balliere Tindall. London: 61-62.

10. Chen Y, Roan H, Lii C, Huang Y, Wang T (2011) Relationship between antioxidant and antiglycation ability of saponins, polyphenols and polysaccharides in chinese herbal medicines used to treat diabetes. Journal of Medicinal Plants Research 5: 2322-2331.

11. Dulekgurgen E (2004) Proteins (Lowry) Protocol. UIUC.
12. Malaysian Standard (2010) MS No. 07U001RO, Phytopharmaceutical aspect of freeze dried water extract from Tongkat ali roots - Specification, Department of Standards Malaysia: $1-13$

13. Goel N, Siroshi SK, Dwivedi J (2012) Estimation of total saponins and evaluate their effect on in vitro methanogenesis and rumen fermentation pattern in wheat straw based diet. Journal of Advanced Veterinary Research 2: 120-126.

14. Thaipong K, Boonprakob U, Crosby K, Zevallos LC, Byrne DH (2006) Comparison of ABTS, DPPH, FRAP, and ORAC assays for estimating antioxidant activity from guava fruit extracts. Journal of Food Composition and Analysis 19: 669-675.

15. Cantin CM, Moreno MA, Gogorcena Y (2009) Evaluation of the antioxidant capacity, phenolic compounds, and vitamin $\mathrm{c}$ content of different peach and nectarine [Prunus persica (L.) Batsch] Breeding Progenies. J Agric Food Chem 57: 4586-4592.

16. Norshazila S, Syed Zahir I, Mustapha Suleiman K, Aisyah MR, Kamarul Rahim K (2010) Antioxidant levels and activities of selected seeds of Malaysian tropical fruits. Malays J Nutr 16: 149-159. [Crossref]

17. Yang Z, Luo S, Peng Q, Zhao C, Yu Z (2007) GC-MS analysis of the essential oil of coral ginger (Zingiber corallinum Hance) rhizome obtained by supercritical fluid extraction and steam distillation extraction. Cromatographia 69: 785-790.

18. Chen ZL, Xu R, Ye Y, Zhao W (2010) Section 1, chemical properties, isolation, and purification. Introduction to Natural Product Chemistry.

19. Griffiths PR, de Haseth JA (1986) Fourier transform infrared spectroscopy. New York. Wiley.

20. Gavamukulya Y, Abou-Elella F, Wamunyokoli F, AEl-Shemy H (2014) Phytochemical screening, anti-oxidant activity and in vitro anticancer potential of ethanolic and water leaves extracts of Annona muricata (Graviola). Asian Pac J Trop Med 4: 930-939. [Crossref]

21. Usunomena U (2012) Review Manuscript: A review of some African medicinal plants International Journal of Pharma and Bio Sciences 3: 1-11.

22. Farnsworth NR, Bederka JP Jr, Moses M (1974) Modern approaches for selecting biologically active plants. I. CNS depressants. J Pharm Sci 63: 457-459. [Crossref]

23. Zohra SF, Meriem B, Samira S, Muneer MS (2012). Phytochemical screening and identification of some compounds from Mallow. Journal of Natural Product and Plant Resources 2: 512-516.

24. Yang H, Li X, Tang Y, Zhang N, Chen J, et al. (2009) Supercritical fluid $\mathrm{CO}_{2}$ extraction and simultaneous determination of eight annonaceous acetogenins in annona genus plant seeds by HPLC-DAD method. J Pharm Biomed Anal 49: 140-144. [Crossref]

Copyright: (C2016 Mat Daud NNNN. This is an open-access article distributed under the terms of the Creative Commons Attribution License, which permits unrestricted use, distribution, and reproduction in any medium, provided the original author and source are credited. 